\title{
STATEMENT OF INTEREST IN CONTRACTS GENERALLY
}

\author{
E. MIRTH*
}

This article limits itself to expression and recoverability of interest on contracts and commercial paper generally. Its aim is to focus on a handful of basic problems encountered in practice from time to time. It will outline the viable opportunities for defence against creditor's claims as well as suggest methods to avoid the pitfalls. The paper does not address the subject of interest in mortgages per se, or the subject of interest as damages. Those are both matters broad enough for separate treatment. What is sought in this article is to wrap up some principles of broad application and to flag some areas in legal practice that appear particularily fruitful either for defence to claims or for improvement of prevailing practices amongst lawyers.

\section{CONTRACTUAL ENTITLEMENT TO INTEREST: BASIC PRINCIPLES}

As a general rule, interest is not due on money secured by a written instrument. Exceptions to this rule occur:

1. Where it appears on the face of the instrument that interest was intended to be paid;

2. Where it is implied from the usage of the trade; ${ }^{1}$

3. Where it is an implied term of a contract; ${ }^{2}$ and

4. Where it is provided for by statute or by rule of court. ${ }^{3}$

If a certain day is fixed for payment of money, a court may imply a contract to pay interest from that day. ${ }^{4}$ Ultimately, contractual entitlement to interest is a question of the construction of the agreement, be it express, implied or customary, between the parties. ${ }^{5}$

If compound interest is not stipulated in the agreement, simple interest is payable. ${ }^{6}$ Where the parties stipulate interest but fail to state a rate, the rate will be five percent per annum. ${ }^{7}$

* With the Firm of Reynolds Mirth \& Cote.

1. Page v. Newman (1892) 9 B \& C 378, 7 L.J. (OS) 267, 109 ER 140 (K.B.); Omichund v. Barker (1945) Ridge temp. H. 285, 27 E.R. 831 (ch.D.); Denton v. Rodie (1813) Camp 493, 170 E.R. 1458. (Nisi Prius).

2. Rhodes v. Rhodes (1860) John 653, 29 LJ Ch. 418, 70 E.R. 581. An agreement to pay interest may be implied from the course of dealings between the parties: Omichund v. Barker, supra n. 1; Denton v. Rodie, supra n. 1; Re Anglesey (1901) 2 Ch. 548; Smith v. McCutcheon [1922] 1 W.W.R. 252 (Sask. C.A.). Such agreement may be inferred from previous dealings between the parties, coupled with printed notification on the statements of account of an intention to charge interest: Marshall Wells Co. Ltd. v. Eaton \& Gordon (1915) 8 W.W.R. 787 (Alta. Dist. Ct.); Pollock v. Feinstein (1942) 2 W.W.R. 517 (Sask. Dist. Ct.).

3. Marshall-Wells Co. Ltd. v. Eaton \& Gordon, supran. 2.

4. Calton v. Bragg (1812) 15 East 223, 104 E.R. 828 (K.B.); Harris v. Benson (1731) 2 Strange 910, 93 E.R. 935 (K.B.).

5. Union Investment Co. v. Wells (1908) 39 S.C.R. 625 (leave refused by Privy Council [1906] A.C. 525).

6. Daniell v. Sinclair (1881) 6 App. Cas. 181, 50 L.J.P.C. 50 (K.B.); James v. Custer [1941] 2 W.W.R. 582 (Man. K.B.); see also Metropolitan Trust Co. Lid. v. Morenish Land Developments Lid. (1980) 118 D.L.R. (3d) 385 (SCC).

7. Interest Act, R.S.C. 1970 , c. 1-18 s. 3; Peterson v. Bitzer [1922] I W.W.R. 141 (SCC). The rate applicable at the time of the agreement will continue even though the statutory rate is subsequently changed; Br. Can. Loan \& Agency Co. v. Farmer (1904) 15 Man. R. 593 (Man. K.B.). 
Except as otherwise provided by the Interest Act of Canada, other federal statutes, ${ }^{8}$ or competent provincial statutes, ${ }^{9}$ "any person may stipulate for, allow and extract, on any contract or agreement whatever, any rate of interest or discount that is agreed upon." 10

The Interest Act ${ }^{11}$ contains a number of relevant restrictions and the provincial unconscionable transactions statutes and the new s.305.1 of the Criminal Code ${ }^{12}$ provide limitations with regard to contracts of loan or credit in general. Generally speaking, the courts are reluctant, apart from statute, to enforce any contracts viewed as unconscionable. ${ }^{13}$

In the absence of a stipulation in the contract setting time for interest payment, it will become payable at the time stipulated for payment of principle. ${ }^{14}$ In the absence of such a stipulation, failure to make interim interest payments will not make the principal fall due. ${ }^{15}$

The Crown is liable to pay interest only by express contract or by statutory requirements. Recent cases in Saskatchewan and British Columbia greatly constrict or even reverse this principle. ${ }^{16}$

Where there is no stipulation as to the rate of interest after maturity of an obligation payable on a specified date, interest may nonetheless be allowed if there is no equitable ground for withholding it; if the Judicature Act is applied, it is payable at the rate stipulated for prior to maturity. However, a stipulation for interest at a stated rate "until paid" may mean only until the maturity date, unless the agreement expressly stipulates the continuance after maturity. ${ }^{17}$ In the latter case only the legal rate may be recoverable after maturity. ${ }^{18}$ To carry interest beyond

8. See the Criminal Code, 1980 , S.C. $1980-81-82.83$, c. 43 , s. 305.1.

9. Such as the Unconscionable Transactions Act, RSA 1980, c. U-2: see A.G. for Ontario v. Barfried Enterprises Ltd. [1963] S.C.R. 570.

10. Interest Act, supra n. 7.

11. Id.

12. Supran. 8.

13. See S.M. Waddams, "Unconscionability in Contracts" (1976) 39 Mod. L. Rev. 369.

14. Finkbeinerv. Yeo(1915) 9 W.W.R. 891 (Man. C.A.).

15. Union Investment Co.v. Wells (1908) 39 S.C.R. 625, revg. (1907) 5 W.L.R. 409.

16. Dunn v. R. (1901) Cout SC Dig. 729; R. v. MacLean (1885) Cass S.C. Dig. 399; Ross v. R. (1902) 32 S.C.R. 532, affg. (1901) 7 EX C.R. 287; Algoma Central Railwayv. R. (1901) 7 EX. C.R. 239, reversed on other grounds, 32 S.C.R. 277, [1903] A.C. 478; Lamarre \& Cie v. R. [1923] EX. C.R. 174; R. v. Rodger Miller \& Sons Lıd. [1923] EX. C.R. 202; R. v. Racette [1948] S.C.R. 28; Oakes v. R. [1944] S.C.R. 138; but see Canadian Industrial Gas \& Oil Ltd. v. Government of Saskatchewan [1978] 6 W.W.R. 477 (S.C.C.); Crown Zellerbach Can. Lid. v. The Queen (1979) 13 B.C.L.R. 276, 11 C.P.C. 187, 101 D.L.R. (3d) 240 revg. (1978) 9 C.P.C. 263,8 B.C.L.R. 187, 92 D.L.R. (3d) 459, (1978) 94 D.L.R. (3d) 479. Leave to Appeal to SCC refused (1979) 30 N.R. 268 (S.C.C.).

17. Trusts \& Guar. Co. v. Continental Supply Co. [1932] 1 W.W.R. 921; Walker v. Card (1915) 7 W.W.R. 1145 (Alta. S.C.T.D.); Kennedy v. Inman [1920] 3 W.W.R. 564 (Alta. S.C.A.D.) Interest may, however, be allowed at only the statutory rate (five percent under the Interest Act, supra n. 7; Cunninghamv. Hamilton(1897) 5 B.C.R. 539 (B.C.Co.Ct.).

18. Hossack v. Shaw (1918) 56 S.C.R. 581, at 585; Peoples Loan \& Deposit Co. v. Grant (1890) 18 S.C.R. 262; St. John v. Rykert (1884) 10 S.C.R. 278; Dominion Meat Co. v. Jamieson [1917] 12 Alta L.R. 353, 3 W.W.R. 929 (Alta. S.C.A.D.). On review, these cases appear in both Walker v. Card and Kennedy v. Inman the Alberta courts awarded interest at the before-maturity rate as a matter of applying Judicature Act provisions empowering the courts to award compensation by way of interest. The Supreme Court of Canada cases above cited proceed on a view of contractual liability only. 
anything but the legal rate after judgment, a clear express statement of that intent is needed. ${ }^{19}$

Whether or not interest beyond the legal rate can ever be validly contracted for or enforced remains unresolved for Alberta law. The stipulation of five percent judgment interest in section 13 of the Interest $\mathrm{Act}^{20}$ applies only to the Northwest Territories and the four western provinces. To date the Courts of those provinces appear split on the question, with the Courts of Appeal in Saskatchewan ${ }^{21}$ and Manitoba ${ }^{22}$ recognizing the ability to do so and the British Columbia Court of Appeal holding the contrary. ${ }^{23}$ The matter remains for definitive resolution in Alberta by a decision of our Court of Appeal and for wider resolution by the Supreme Court of Canada. ${ }^{24}$

An interest rate in any contract (other than mortgages, which are governed by section 6 of the Interest Act) ${ }^{25}$ must be expressed as a yearly rate or percentage of interest and, failing that, only the legal rate (five percent) is recoverable. ${ }^{26}$

A complete description of interest should describe both the period of calculation and the period of compounding. Although Woodard ${ }^{27}$ in his book on Canadian mortgages suggests that "calculated" and "compounded" are one and the same thing, as does a recent judgment in the Supreme Court of Canada, ${ }^{28}$ these terms of ten express different concepts in many legal documents. A conventional mortgage which provides for interest only payments each month would probably speak of interest as being "calculated monthly not in advance". Thus the interest payable each month is based on exactly one-twelfth of the stated annual percentage. The same mortgage may provide for "compounding" only semi-

19. Bank of Nova Scotia v. U.P.C. Holdings Ltd. (1980) 11 Alta L.R. (2d) 331; see also decision of Master Funduk in Maple Credit Lid. v. Xomox Investments Ltd. (1982) 21 Alta L.R. 289, and unreported decision of Mr. Justice Laycraft in Zero Stores (Sask.) Ltd. v. KAH Investments Ltd. (Calgary Appeal No. 14391).

20. Supran. 7.

21. Regina Steam Laundry v. Saskatchewan Government Insurance Office [1971] 1 W.W.R. 96. (Sask. C.A.).

22. Chin-Si Thoo v. Berry [1978] 2 W.W.R. 641 (Man. Q.B.); Banfield, McFarlane, Evans Real Estate Limited v. Hoffer [1977] 4 W.W.R. 465 (Man. C.A.).

23. Norfolk Trust v. Wolcoski[1982] 6 W.W.R. 189 (B.C.C.A.).

24. The approach of the Supreme Court in Prince Albert Pulp Co. Ltd. v. Foundation Co. [1977] I S.C.R. 200 is interesting, although not directly on point. The court there was dealing with interest in the context of a damage award; and seems to have felt the need to work around the provisions of the Interest Act by finding the award of interest in the context of damages to be part of the damage judgment itself. Does that mean that the Court viewed the stipulations in s. 13 as unavoidable? Section 2 of the Interest Act permits freedom as to interest stipulation "except as otherwise provided" in the Act. If the word "prohibited" had been used, or if s. 13 had been in a "prohibition" format, the answer to the conflict between the western courts' decisions would have been easier to resolve; but the use of the word "provided" rather than "prohibited" may prove very significant in the ultimate resolution of the matter, if the approach of this Supreme Court decision is any indication.

25. Supra n. 7, s. 4. Although Section 4 excludes all mortgages, s. 6 clearly has something of its own to say about mortgages payable by a sinking fund plan or by blended payments.

26. See Cruikshank v. Murphy Campbell Co. (1958) 13 D.L.R. (2d) 250 (B.C.S.C.).

27. Woodard, Canadian Mortgages, p. 192.

28. See Mr. Justice Estey's judgment in Metropolitan Trust Co. Ltd. v. Morenish Land Developments Ltd., supra n. 6. 
annually; that is, for interest calculation purposes the interest in arrears is to be added to the principal every six months.

The importance of correct expression of interest calculation periods is well stated by Woodard in the following passage: ${ }^{29}$

\begin{abstract}
Just as the frequency of compounding, as expressed by the word "calculated" or its synonyms, has no bearing on when the interest is to be paid, neither has it any necessary bearing on how frequently the lender may charge the interest to the borrower's account. There is often some confusion on this point owing to the misunderstanding of the word "calculated" in its mathematical sense. For example, an interest rate may be expressed as "calculated semi-annually", yet the borrower may contract to pay the interest monthly. The lender, in turn, may be charging the borrower's account with interest each month. There is nothing incorrect in such procedures, provided (and it is an important proviso) that the effective annual yield to the lender is not higher than that derived from the contractual interest rate. When interest is payable by the borrower more frequently than once each period of compounding as expressed in the contractual interest rate, all interest mathematics are based on the theory that the lender re-invests the interest received from time to time, at the same rate. Therefore the amounts of interest received from the borrower, plus the theoretical re-investment earnings on them, produce, for the lender, the effective yield contemplated in the borrowing instrument, be it mortgage deed, promissory note, or otherwise.

Following along this principle then, it will be apparent immediately that if, for example, the contractual rate is " $6 \%$ calculates semi-annually not in advance", the lender cannot collect $1 / 2 \%$ each month, for that would be a rate of " $6 \%$ calculated monthly not in advance" and would be an over-charge. However, if the borrower is paying his interest monthly and the lender wishes to charge the interest to the account monthly, then some rate of charge must be determined which is the proper equivalent and which obviously must be less than $1 / 2 \%$ each month. To allow the monthly or other periodic charging and collection of interest without impairment of the contractual rate, mathematicians provide us with the applicable figures to be used when payments of interest are to be made and charged more often than the interest is to be compounded, calculated, or converted, according to the rate established in the contract. These figures are generally known, in the mortgage business, as interest factors. Thus, in the previous example, where interest is being collected and charged monthly, on a mortgage loan on which the interest rate is " $6 \%$ calculated semi-annually not in advance", the lender would charge $.493862 \%$ at the end of each month." (Which expressed annually would be $5.926344 \%$ calculated monthly.)
\end{abstract}

The existence of a "reinvestment principle" as one recognizable and operable in law would seem to have been accepted by the Supreme Court of Canada in Standard Reliance Mortgage Co. v. Stubbs. ${ }^{30}$ However, its operation is somewhat confounded by the language of the decision in the Metropolitan Trust ${ }^{31}$ case. In essence the Court in Metropolitan Trust decided that on review of all the applicable mortgage terms, the particular mortgage the court was dealing with impliedly intended monthly (not annual) calculation. The discussion of the reinvestment principle in this recent case may well be obiter and one must surely continue to have regard for the judgment of Mr. Justice Anglin in Standard Reliance that was not directly overruled.

While these variations may seem too small to worth bothering with, (using the numbers Woodard does) one need only apply them to a $\$ 10,000,000.00$ contract to see how relevant they can become. ${ }^{32}$

29. Supra n. 27 at pp. 192-193.

30. (1917) 55 S.C.R. 422.

31. Supran. 28.

32. In the Metropolitan Trust case, supra n. 6, the factoring meant hundreds of thousands of dollars. 
With these basic principles in mind, it is proposed now to discuss various kinds of agreements and instruments commonly in use. ${ }^{33}$

\section{COMMERCIAL PAPER AND CONTRACTS GENERALLY}

While institutional mortgage lenders have long been sophisticated in their approach to full and correct identification and delineation of interest, the same is rarely true of interest stipulations in various forms of commercial paper and contracts. Yet there is little reason to believe that all of the principles previously related in the context of mortgages would not equally apply to a promissory note, a construction contract providing for interest past due dates, or a debenture. For example, a contract that provides for interest at two percent per month (and no more) violates s.4 of the Interest Act; ${ }^{34}$ that will be true whatever the form or nature of the contract (other than mortgages, which are expressly excepted). It will apply even to promissory notes. ${ }^{35}$ Yet it is common to find all kinds of agreements, order forms, invoices and other documents in commercial use that stipulate interest past due dates in monthly, not annual terms.

Similarly, it is not uncommon (and may well be the rule rather than the exception) for contracts of all kinds to neglect to stipulate either the period of calculation or any concept of compounding applicable to an expressed interest rate. Failure to express the period of calculation where payments are made more frequently than annually may require application of the re-investment principle $\mathrm{e}^{36}$ and factoring (or discounting) of the rate chargeable accordingly. The rate "six percent per annum", simpliciter, means six percent per annum calculated annually, not in advance. If payments are to be made monthly, the equivalent rate for monthly calculation would be 0.493862 percent per month (ie. 5.9263 percent per annum calculated monthly, not in advance). ${ }^{37}$

Failure to expressly provide for compounding will not permit compounding to occur ${ }^{38}$ Failure to expressly provide for interest after default ${ }^{39}$ and a fortiori after judgment ${ }^{40}$ will disentitle the payee to interest after those events.

Thus, a promissory note promising to pay " 30 days after date the principal sum of $\$ 1,000.00$ together with interest thereon from the date hereof at twelve percent per annum" may not allow for interest after thirty days (except to the extent mentioned below). A debenture providing for payment of $\$ 100,000$ on June 1, 1984, and payment of "interest on such sum at the rate of $12 \%$ per annum by equal monthly instalments on

33. Again leaving aside those two special subject matters referred to in the introduction to this paper.

34. Supran. 7.

35. Barbourv. Paradis (1929) 68 Que. S.C. 31.

36. See Metropolitan Trust Co. v. Morenish Land Development Co. Lid., supra n. 6; Shoyle Holdings Ltd. v. Hunter (1980) 19 B.C.L.R. 359 (B.C.S.C.).

37. Supra n. 26 at 194.

38. Supran. 6.

39. Supran. 17 and 18.

40. Supra n. 19, Maple Credit. 
the 1st day of each month from June 1, 1983 to June 1, 1984" will probably:

1. Require the factoring, by the reinvestment principle, of the twelve percent rate;

2. Fail to permit any compounding; and

3. Fail to permit recovery of interest after June 1, 1984, except perhaps at five percent or, if one can convince a Court to apply s. 10 of the Judicature Act, at twelve percent.

A standard "non-merger" on judgment clause in the instrument will probably not alter the third result. ${ }^{41}$

The note will probably not afford acceleration, or indeed recourse for anything other than the missed instalments. In the absence of an acceleration clause, ${ }^{42}$ each instalment is to be considered a separate debt. ${ }^{43}$

\section{A FEW SPECIFICS ON PROMISSORY NOTES}

Some additional points should be made in the specific context of promissory notes. Unlike other common commercial paper and contract forms, they are limited by fairly comprehensive statutory requirements and rules. The following sections of the Bills of Exchange Act $^{44}$ are relevant to the matters of interest:

A. Section $176(1)$ provides that to be a promissory note the instrument must be for a sum certain in money:

(1) A promissory note is an unconditional promise in writing made by one person to another, signed by the maker, engaging to pay, on demand or at a fixed or determinable future time, a sum certain in money, to, or to the order of, a specified person, or to bearer.

Three recent cases raise the possibility that a note providing for interest at the "bank rate", or some sort of prime rate plus, may not be a promissory note. The first case was MacLeod Savings \& Credit Union Ltd. v. Pevett. ${ }^{45}$ In that case, a note called for payment of interest from the date of advances made by the lender. Those dates were not apparent on the face of the note and the Supreme Court of Canada held the instrument not to be for a "sum certain" and therefore not to be a promissory note. In obiter, the Court referred to "notes" at interest rates tied to the "bank rate" and expressly wondered whether such "notes" would truly be promissory notes by virtue of section 176(1).

In Bank of Montreal v. Dezcam Indutries Ltd. ${ }^{46}$ the British Columbia Court of Appeal held that a note stipulating a rate based on a rate charged by a bank to "its most credit-worthy customers" was not for a sum certain, as evidence indicated there were varying rates applicable to various loans and borrowers.

\footnotetext{
41. Id.

42. Which is permitted by s. $28(1)$ (c) of the Bills of Exchange Act, R.S.C. 1970, c. B-5. See also Carlon v. Kenealy (1843) 12 M \& W 130 (Ex).

43. Clearihuev. Morris (1820) 2 Rev. de Leg 30.

44. R.S.C. 1970 , C. B-5.

45. (1981) 1 S.C.R. 78, 118 D.L.R. (3d) 193.

46. [1983] 5 W.W.R. 83. (B.C.C.A.).
} 
In Bank of Montreal v. A. \& M Investments Ltd. ${ }^{47}$ Mr. Justice Noble of the Saskatchewan Court of Queen's Bench applied the MacLeod Savings case to rule that a "note" providing for interest at a rate of " $13 / 4 \%$ per annum above the Bank of Montreal's Small Business Base interest rate per annum in effect from time to time" was not for a "sum certain" and therefore not a promissory note. However, the Court gave effect to the "note" to grant judgment against the drawer, as for money payable by a contract for repayment.

In some cases, however, the identity of the instrument as a promissory note could be crucial. In the MacLeod Savings case, for example, its lack of such character relieved an endorser or accomodating party from liability in the absence of proper notary public certification of the endorsement "guarantee". In the case of a credit union governed by the Credit Union Act of Alberta, ${ }^{48}$ which requires all loans to be supported by a promissory note (or a line-of-credit agreement), such a decision could raise the argument that the loan was ultra vires the credit union. ${ }^{49}$

B. Other sections of the Bills of Exchange Act that should also be kept in mind when dealing with instruments governed by such Act are:

1. Section 28(1):

(1) the sum payable by a bill is a sum certain within the meaning of this Act, although it is required to be paid:

(a) with interest;

(b) by stated instalments;

(c) by stated instalments, with a provision that upon default in payment of any instalment the whole shall become due; or

(d) according to an indicated rate of exchange or according to a rate of exchange to be ascertained as directed by the bill.

2. Section 298(3):

(3) Where a bill is expressed to be payable with interest, unless the instrument otherwise provides, interest runs from the date of the bill, and if the bill is undated, from the issue thereof.

\section{Section 134:}

Where a bill is dishonoured, the measure of damages, which shall be deemed to be liquidated damages, are:

(a) the amount of the bill;

(b) interest thereon from the time of presentment for payment, if the bill is payable on demand, and from the maturity of the bill in any other case; and

(c) the expenses of noting and protest.

This section supplements the interest payable by the note itself and deals with interest as damages for non-payment. As previously indicated, such interest would, by section 3 of the Interest Act, ${ }^{50}$ be five percent; presumably the Court could award a higher rate if deemed mete under the Judicature Act for promissory notes and other contracts. ${ }^{51}$

47. (1982) 136 D.L.R. (3d) 181 (Sask. Q.B.).

48. RSA 1980 , c. C-31, s. 32.

49. Although such ultra vires argument seems unlikely to succeed today in complete avoidance of the loan in the light of cases such as Re: H.A. Walker \& Associates (1979) 90 D.L.R. (3d) 294 affirmed; 250 R (2d) 60 (C.A.); and London \& Harrogate Securities Ltd. v. Pitts [1976] 1 W.L.R. 264 (Q.B.).

50. Supran. 7.

51. Supran. 17 and 18. 
Interest on interest (ie. compounding), however, will not be sanctioned by this section. ${ }^{52}$

\section{Section 145:}

(1) Subject to subsection (2), where a bill or acceptance is materially altered without the assent of all parties liable on the bill, the bill is voided, except as against a party who has himself made, authorized, or assented to the alteration and subsequent endorsers.

(2) Where a bill has been materially altered, but the alteration is not apparent, and the bill is in the hands of a holder in due course, such holder may avail himself of the bill as if it had not been altered, and may enforce payment of it according to its original tenor.

In Royal Bank of Canada v. Davidson, ${ }^{53}$ a bank followed a system (quite common a few years back) of obtaining promissory notes at fixed rates with the intent that every time a prime rate change occurred a new note would be taken. The latter step tended to be omitted and the bank simply issued notices of rate changes. The borrower raised s.145 and claimed that the bank's notices were material alterations. The argument did not succeed but it is interesting to note that such failure was largely due to the fact that the borrower in fact paid pursuant to the notices. More interestingly, the court applied the last note rate (seven and threequarter percent) as opposed to the last notified rate (nine and one-quarter percent) from the date of the last payment made.

\section{MISCELLANEOUS PROBLEMS}

It is not uncommon to find contracts of various kinds attempting to give bonuses or add penalties to encourage prompt payment. On mortgages such concepts, however cast, tend to fail by virtue of section 8 of the Interest Act. ${ }^{54}$ That section, however, applies only to mortgages and there are no similar statutory provisions dealing with agreements for sale and other contract forms. Indeed, promissory notes with a bonus for prompt payment have been recognized as being valid. ${ }^{55}$

One must always be mindful of the ability (and indeed the predisposition) of the Courts to decline to enforce a penalty. ${ }^{56}$ However, a bonus or other arrangement to encourage prompt payment is cast, ${ }^{57}$ and the arrangement will remain liable to the defense of penalty. Of course, expression of the arrangement as a penalty would increase the risk of such a defense succeeding.

One frequently encounters, particularly in commercial and construction transactions, various kinds of attempts to "foist" interest. For example, an invoice of a supplier of building materials will commonly state on its face that interest will be payable on over-due accounts at some

52. Newago Co.v. Russell(1921) 22 O.W.N. 366; affg. 21 O.W.N. 47.

53. (1972) 25 D.L.R. (3d) 202 (N.S.C.A.).

54. Supran. 7.

55. First National Bank v. Rooney(1913) 6 Sask. 72 (Sask. S.C.).

56. As reflected in s. 10 of the Judicature Act R.S.A. 1980, c. J-1; see also World Land Ltd. v. Daon [1982] 4 W.W.R. 577 (Alta. Q.B.); but see Popyle v. Western Savings \& Loan Association (1969) 67 W.W.R. 684 (Alta. CA).

57. See, however, the decision of Master Hyndman in MacDonaldv. Muncy, [1980] 4 W.W.R. 554 (Alta. Q.B.). 
stipulated rate. ${ }^{58}$ Except to the extent that the Courts have power to award interest as a damage item for wrongful withholding of payment, entitlement to interest is a matter of contract. It goes without saying that a contract cannot be unilaterally imposed. ${ }^{59}$ If a party to a transaction has not in some manner or by some means accepted the obligation to pay interest, he will not as a matter of contract be obligated to pay it. Such acceptance may occur, however, in a number of ways. If the parties enter into a binding contract for payment of interest, it will be recoverable. Such a contract may even occur without clear form. If a supplier provides an order form to a purchaser that expressly stipulates interest and the purchaser uses that form to order goods, then clearly when the goods are supplied, the purchaser is bound to pay interest. Similarly, where a transaction is done in circumstances where by usage of trade interest is payable on late payment, then ordering goods in the context of such usage may generate contractual liability for interest. Where by previous conduct the parties come to expect interest to be charged, an implied agreement to pay may arise on a new contract. ${ }^{60}$ Where, however, a supplier as a matter of his own practice charges interest and the purchaser first becomes aware of such practice only after the purchase is made, contractual liability for interest is unlikely. ${ }^{61}$

The matter of exaction of interest has special problems for lawyers. It is uncommon for lawyers to stipulate at the time of or in conjunction with their being retained what precisely the fee will be, much less any rate of interest applicable to late payment. Yet one does see, from time to time, legal accounts with interest stipulations on the bottom line. ${ }^{62}$ The rules, of course, are not better disposed towards lawyers than towards others. Indeed, the Law Society of Alberta has quite distinct views on the ability and the suitability of lawyers exacting interest on unpaid accounts. The matter is covered in a recently publicized ruling of the Ethics Committee: 63

The Ethics Committee has been asked if it is proper for lawyers to charge interest on overdue accounts. This question was the subject of a judgment by the Honourable Mr. Justice Cavanagh in recent months. The Committee's opinion is that it is undignified and accordingly improper to state at the bottom of accounts that interest will accrue if the account is not paid within a specific period of time. However, it is not improper for a lawyer on reasonable notice to claim interest under The Judicature Act if payment of an account is unjustly withheld.

58. All too often a rate per month only is stated; and quite apart from the question of entitlement to "foist" interest, s. 4 of the Interest Act, as indicated above, has something to say about the rate actually payable.

59. See Cheshire and Fifoot's Law of Contract, (Tenth ed., 1981) chapter 3. See also Kenton Consumers Coop Ltd. v. Archibald (1954) 13 W.W.R. 594 (QB) where Freedman, J. (as he was then) ruled that a statement on invoices was not enough to yield implied agreement; and Erin Iron Works v. Fleetwood Homes [1980] 3 W.W.R. 140 (Man. Co. Ct.). See also Fowle v. Klassen (infra); Evergreen Irrigation v. Belgian Farms (1976) 3 A.R. 248 (Alta. S.C.T.D.).

60. Marshall-Wells Co. Inc. v. Eaton \& Gordon, supra n. 2.

61. See Erin Iron, supra n. 59.

62. Sometimes, surprisingly enough, expressing only a monthly rate of interest, not an annual equivalent.

63. See the Law Society of Alberta/Canadian Bar Association, Alberta Br. Newsletter for Oct/Nov 1980. 
The case referred to is the decision of Mr. Justice Cavanagh in Fowle v. Klassen. ${ }^{64}$ It is interesting to note that the Court suggested that if a lawyer were to stipulate in advance for interest and agreement is reached for payment of interest, such agreement would have to be deposited with the taxing officer pursuant to Rule 646. Mr. Justice Cavanagh reiterated, as well, the principle that one cannot foist interest ex poste facto. $\mathrm{He}$ also declined to award interest under s.34(16) of the Judicature Act.

\section{PRACTICE PROBLEMS AND SHORTCOMINGS}

One will find a multitude of expressions of interest in contracts in use today. Some, alas, are sufficiently vague to be arguably void for uncertainty. Many, though not void, fail to do what the parties actually intended.

As previously suggested, quite a common failing is to disregard the need for specificity of periods of calculation. For example, if parties to an agreement for sale or mortgage provide for interest payments only, they probably intend interest to be calculated monthly, not in advance. On a $\$ 10,000,000.00$ principal sum at twelve percent, they probably expect the monthly payment to be one percent per month, or $\$ 100,000.00$. Unfortunately, quite of ten the rate will be expressed either as " $12 \%$ per annum" (without any reference to period of calculation), or more commonly " $12 \%$ per annum, calculated semi-annually, not in advance". In both cases factoring is required, although to a lesser extent for the second example. ${ }^{65}$ On a five year term, the first failure could cost someone close to $\$ 341,250.00$ and the second $\$ 180,000.00$. The need for precision is not a small matter where the principal sum is large.

Mortgages always seem to be connected with the concept of semiannual calculation. Even on the conventional term, principal-andinterest-payment, mortgage the lender in fact will exact interest up to the interest adjustment date based on a monthly or even daily calculation (ie., completely unfactored). For that process to be properly cast in the mortgage instrument, it should provide for two rates:

1. Interest calculated monthly to the Interest Adjustment Date, and

2. Interest calculated semi-annually from and after the Interest Adjustment Date.

The standard stationer form documents, in some cases, fail to deal with interest fully. For example, at lease one particular mortgage form is designed for annual payments only, and therefore omits reference to the period of calculation. If it is used for monthly payments, the period of calculation should be expressly addressed by an insertion into the form. The same form also fails to state the date from which calculation is to be made, which should in all cases be stipulated.

A standard stationer's form of chattel mortgage fails to address any of the dates from which interest is to be calculated, the period of calcula-

64. (1980) 31 A.R. 494 (Alta. Q.B.).

65. Supran. 27 at 194. 
tion, and the recoverability of the stated rate both before and after judgment.

On a vendor take-back mortgage, the date from which interest is calculated should always be stated, and will normally be the closing date.

Two standard agreement for sale forms in common use make no reference at all to periods of calculation, notwithstanding the fact that the practice on an agreement for sale with monthly payments is for the interest to be paid and calculated monthly. Neither form adequately deals with interest after default or judgment.

Definition of a floating rate of interest can be a difficult exercise in precision drafting. Various terms are encountered: "bank prime", "minimum lending rate", "prime small business base rate". None of these terms are meaningful in themselves. Even the term "prime rate" needs definition. A bank's "prime rate" may differ for a loan in U.S. dollars from the rate applicable to a Canadian-dollar loan. The "prime rate" for a small business may differ from the "prime rate" for a large corporate commercial borrower. A change in rate may occur mid-day. All of these variables should be addressed to achieve certainty of term. A properly drawn "prime rate" stipulation should at least:

1. Name the bank and the branch from which the rate is to be ascertained (usually the "Main Branch" in some stated city.);

2. Refer to the kind of borrower (usually something like "the largest commercial borrowers of the highest commercial standing"');

4. Address the period of calculation: the "prime rate" is usually a rate calculated monthly, not in advance;

4. Identify place and variety of loan: eg., "Canadian dollar loans made in Canada for short-term-unsecured loans".

5. Specify how the rate is to be determined (eg., by letter from the Manager or Assistant Manager of the stated branch), and, more importantly describe the rate as the rate "published from time to time as being the bank's prime rate"; and

6. State at what moment the rate will be taken. For example, some lenders prefer to set the rate for the month as of the first day of the month; that requires specification. Others prefer to have the rate vary daily as bank prime changes; that requires a different form of specification. If rates can change mid-day, one should address which rate (usually the highest) will apply to that day.

It is also useful, even with all these points covered, to be able to install a fall-back rate in the event that the "prime plus" rate fails. For example, a stipulation that if the rate based on prime is indeterminate or unascertainable for any reason the rate would then be X. Remember in this regard that the MacLeod Savings case ${ }^{66}$ suggests the possibility that a note "with bank interest" may not be for a sum certain. The same concern for certainty of term would apply to any contract.

Interestingly enough, the same institutional lenders who take care with interest definition in mortgage documents often, when mortgage

66. Supran. 45 at 197. 
renewals occur, seem to forget completely why such care is needed. Renewals of ten occur by simple letter form, and more of ten by one-page renewal instruments. Few of the renewals examined accurately or fully described the intended interest rate. Calculation date, calculation period, and rates after maturity and judgment are forgotten matters. The result may well be the material alteration of what was once a clear-cut and precise mortgage instrument into an instrument of at least some ambiguity and perhaps even uncertainty of term.

Expression of rates in more esoteric forms such is $\mathrm{LIBOR}^{67}$ rates is particularly tricky. Such rates, like the bank prime rates, may arguably violate s.3 of the Interest $\mathrm{Act}^{68}$ which seems to require a rate to be "fixed" by an agreement. Although it is possible that the term "fixed" could be construed much more narrowly than "stated" or "ascertained", a recent case in Ontario, the Mason ${ }^{69}$ case suggests that reference even to a LIBOR rate would fall within the requirements of section 3 . However the same case at trial held that a LIBOR rate does violate 5.4 of the Interest Act, ${ }^{70}$ which requires rates to be expressed as annual rates. LIBOR rates are expressed in terms of 360 day years ${ }^{71}$ and most years comprise 365 days. In the Mason case a Bank, having failed to quantify its 360-day rate in annual terms, was reduced at trial to recovery of a five percent return. It was not saved by a collateral mortgage debenture, which indicates the importance always of identifying and analyzing the root document. While in further appeal to the Court of Appeal, ${ }^{72}$ the Court reversed this part of the decision, it did so on the basis that the commitment letter and debenture were in substance a mortgage and governed by s.6, not s.4 of the Act. Furthermore, leave to appeal to the Supreme Court of Canada has been granted..$^{73}$

Stuart Cobbett, in an article in the 1981 Meredith Memorial Lectures, ${ }^{74}$ suggests that all loan agreements and instruments using rates like LIBOR rates should contain a provision stating:

The yearly rates of interest to which the rates determined in accordance with this agreement are equivalent, are the rates so determined divided by 360 and multiplied by the actual number of days in the year.

One might add, should the period of calculation and payment in arrears, as well as payment before and after maturity and judgment also be expressly addressed? This is raised by Cobbett's note, ${ }^{75}$ although Cobbett goes on to suggest that statement of an effective rate is not required. ${ }^{76}$

67. London Interbank Eurodollar Offer Rate.

68. Supran. 7.

69. V.K. Mason Construction Ltd. v. Courtot Investments Ltd. (1981) 10 B.L.R. 77 (Ont. S.C.).

70. Supran. 7.

71. See Stuart Cobbett, "Loan Agreements - Interesting and Demanding", (1981) Meredith Memorial Lecturesp. 314 at p. 317.

72. (1982) 39 O.R. (2d) 630. Note as well the difference between the Banker's claim in Mason and its recovery in the case was $\$ 1,058,000.00$.

73. (1983) 40 O.R. (2d) 404 at

74. Supran. 71.

75. Id. at 318.

76. Cobbett also expresses some interesting observations on "prime rate", id. at 323. 


\section{CONCLUSION}

Cases on the application of terms of interest and their misapplication are just beginning to come before the courts with noticeable frequency. This may be a reflection of the economic times or a reflection of increasing awareness of the complexity of the subject matter. As the Mason case illustrates, the matter of interest is not always a "simple" matter. It behooves all practitioners to treat it with more respect and care. 